Supporting Information

\title{
Poly(glycidyl methacrylate-co-2-hydroxyethyl methacrylate) Brushes as Peptide/Protein Microarray Substrate for Improving Protein Binding and Functionality \\ Zhen Lei, ${ }^{\dagger, t}$ Jiaxue Gao, ${ }^{\dagger,+}$ Xia Liu, ${ }^{\dagger}$ Dianjun Liu ${ }^{\dagger}$ and Zhenxin Wang $*^{\dagger}$
}

${ }^{\dagger}$ State Key Laboratory of Electroanalytical Chemistry, Changchun Institute of Applied Chemistry, Chinese Academy of Sciences, Changchun 130022, P. R. China.

†University of Chinese Academy of Sciences, Beijing 100049, P. R. China

*Corresponding author information

E-mails: wangzx@ciac.ac.cn

Table of Contents

Additional experimental section

Additional Figures S1-S8 


\section{Additional experimental section}

Fabrication of protein microarray The human $\mathrm{IgG}$ and rabbit antihuman $\mathrm{IgG} / \mathrm{Cy} 3$ were dissolved in the spotting solution (PBS ( $\mathrm{pH} 7.5,50 \mathrm{mM} \mathrm{PB}, 0.15 \mathrm{M} \mathrm{NaCl}$ ) supplemented with $30 \%$ (v/v) glycerol) and spotted on P(GMA-HEMA) brush substrates and commercial 2D epoxy glass slides using a SmartArrayer 136 system (CapitalBio Ltd., Beijing, China). After an overnight incubation under vacuum at $30{ }^{\circ} \mathrm{C}$, the slides were rinsed with washing buffer (PBS (pH 7.5, $50 \mathrm{mM} \mathrm{PB,} \mathrm{0.15} \mathrm{M} \mathrm{NaCl)} \mathrm{with} 0.05 \%(\mathrm{v} / \mathrm{v})$ Tween-20), and then incubated in PBS containing $1 \%(\mathrm{w} / \mathrm{v}) \mathrm{BSA}$ and $1 \%(\mathrm{v} / \mathrm{v})$ ethanolamine for $1 \mathrm{~h}$ to inactivate remaining free oxirane groups on the slide surface. In order to evaluate the immobilization efficiencies of the two slides for protein, after the block step, the slides were scanned with a LuxScan-10K fluorescence microarray scanner (CapitalBio, Beijing) to obtain the fluorescence intensity of rabbit antihuman $\mathrm{IgG} / \mathrm{Cy} 3$ which was directly spotted on the slides. Subsequently, the slides were washed by washing buffer, and separated into 12 independent subarrays by PTFE grids for further use.

Fabrication of peptide microarray Peptide substrates in spotting solution (PBS ( $\mathrm{pH} 8.5$, $0.3 \mathrm{M} \mathrm{PB}, 0.2 \mathrm{M} \mathrm{NaCl})$ with $20 \mu \mathrm{g} \mathrm{mL} \mathrm{mL}^{-1} \mathrm{BSA}$ and $35 \%$ (v/v) glycerol) with desired concentrations were spotted onto P(GMA-HEMA) brush substrates and commercial 2D epoxy glass slides using a SmartArrayer 136 system (CapitalBio Ltd., Beijing, China). After an overnight incubation under vacuum at $30{ }^{\circ} \mathrm{C}$, the slides were washed with phosphate buffer $(\mathrm{pH} 7.5,50 \mathrm{mM})$ supplemented with $1 \%(\mathrm{w} / \mathrm{v}) \mathrm{BSA}$, and then incubated in blocking buffer 
(pH 7.5, $50 \mathrm{mM} \mathrm{PB}, 0.15 \mathrm{M} \mathrm{NaCl}$ containing $1 \%(\mathrm{w} / \mathrm{v}) \mathrm{BSA}$ and $1 \%(\mathrm{v} / \mathrm{v})$ ethanolamine) for 1 $\mathrm{h}$ to inactivate remaining free oxirane groups on the slide surface. After the blocking reaction, the slides were subjected to a series of washing steps: (1) $30 \mathrm{~mL}$ Milli-Q water for $3 \mathrm{~min}$ (3 times), (2) $30 \mathrm{~mL}$ of washing buffer (pH 7.5, $20 \mathrm{mM}$ Tris, 0.15 M NaCl, $10 \mathrm{mM}$ EDTA-Na 2 with $0.1 \%$ Triton $\mathrm{X}-100)$ for $10 \mathrm{~min}$ (2 times), and (3) $30 \mathrm{~mL}$ of TCNB buffer (50mM Tris, $10 \mathrm{mM} \mathrm{CaCl}_{2}, 150 \mathrm{mM} \mathrm{NaCl}$ and $0.05 \%$ Brij-35, $\mathrm{pH} 7.5$ ) for $10 \mathrm{~min}$ (2 times), respectively. After dried by centrifugation, the peptide microarray was divided into 10 independent subarrays by a PTFE mask, and employed to detect the activities of MMPs. As for the immobilization efficiencies of the two slides for peptide, the slides were scanned after the reaction with avidin-Cy3.

Assaying the pure MMP activities $10 \mathrm{nM}$ proMMP-2 and/or proMMP-9 was activated by $1 \mathrm{mM}$ APMA in TCNB buffer (50 mM Tris, $10 \mathrm{mM} \mathrm{CaCl}_{2}, 150 \mathrm{mM} \mathrm{NaCl}$ and $0.05 \%$ Brij-35, $\mathrm{pH}$ 7.5) for $1 \mathrm{~h}$. Subsequently, $27 \mu \mathrm{L}$ of the solutions containing various concentrations of activated pure MMP-2, MMP-9 or the MMP mixture (MMP-2:MMP-9=1:1 (mass ratio)) were applied to each subarray and incubated at $37{ }^{\circ} \mathrm{C}$ for a period of time. After the PTFE grids were removed, the microarrays were washed with $30 \mathrm{~mL}$ of washing buffer $(\mathrm{pH} 7.5,20 \mathrm{mM}$ Tris, $0.15 \mathrm{M} \mathrm{NaCl}, 10 \mathrm{mM}$ ethylenediaminetetraacetic acid disodium salt (EDTA-Na $)$ with $0.1 \%$ Triton $\mathrm{X}-100)$ for $5 \mathrm{~min}$ (3 times), $30 \mathrm{~mL}$ of washing buffer without Triton $\mathrm{X}-100$ for 5 $\min$ (3 times), and $30 \mathrm{~mL}$ of water for $3 \mathrm{~min}$ (3 times). After drying by centrifugation, the microarrays were separated into 10 independent subarrays with new PTFE grids. 
Subsequently, $27 \mu \mathrm{L}$ of avidin-Cy3 $(50 \mathrm{nM})$ in probe buffer (PBS supplemented with $1 \%$ BSA (w/v) and $0.1 \%$ Tween-20 (v/v)) was applied to each subarray followed by incubation at $37{ }^{\circ} \mathrm{C}$ for $1 \mathrm{~h}$. Then, the subarrays were washed and dried as described before. The subarray incubated with blank TCNB buffer was used as the control experiment.

Determining the activities of cell-secreted MMP-2 and MMP-9 For the off-chip cultured cells, MDA-MB-231 cells were seeded in a 48-well culture plate at the desired densities and grown in fresh L-15 culture media supplemented with $10 \%$ fetal bovine serum (FBS) and 100 $\mathrm{U} \mathrm{mL}^{-1}$ penicillin-streptomycin in humidified air without $\mathrm{CO}_{2}$ at $37{ }^{\circ} \mathrm{C}$ for $24 \mathrm{~h}$. After washing with PBS $(300 \mu \mathrm{L}$, twice), the cells were starved in serum-free L-15 medium for $12 \mathrm{~h}$. Then, the starved cells were co-cultured with various concentrations of PMA in serum-free culture medium for an additional $24 \mathrm{~h}$. The conditioned medium was collected and centrifuged (10 $\min , 1000 \mathrm{rpm}$ ) at $4{ }^{\circ} \mathrm{C}$. After adjusting the $\mathrm{pH}$ to 7.5 , the collected supernatants were applied to the subarrays ( $27 \mu \mathrm{L}$ per subarray) and treated as previously described to determine the activities of pure MMP-2 and MMP-9.

Cell staining with calcein-AM and propidium iodide (PI) When cells were cultured on the P(GMA-HEMA) brush substrate spotted with the mixture of MMPs substrates and RGD-containing peptide or on blank polymer brush-coated surface for $24 \mathrm{~h}$, the culture media was removed, and the cells were washed by PBS twice. Then the cells were incubated with 2 $\mu \mathrm{M}$ calcein $\mathrm{AM}$ and $4 \mu \mathrm{M}$ PI in fresh culture medium for $20 \mathrm{~min}$. Subsequently, the cells were washed by PBS and imaged by Nikon Ti-S fluorescent microscope (Nikon, Tokyo, Japan). 


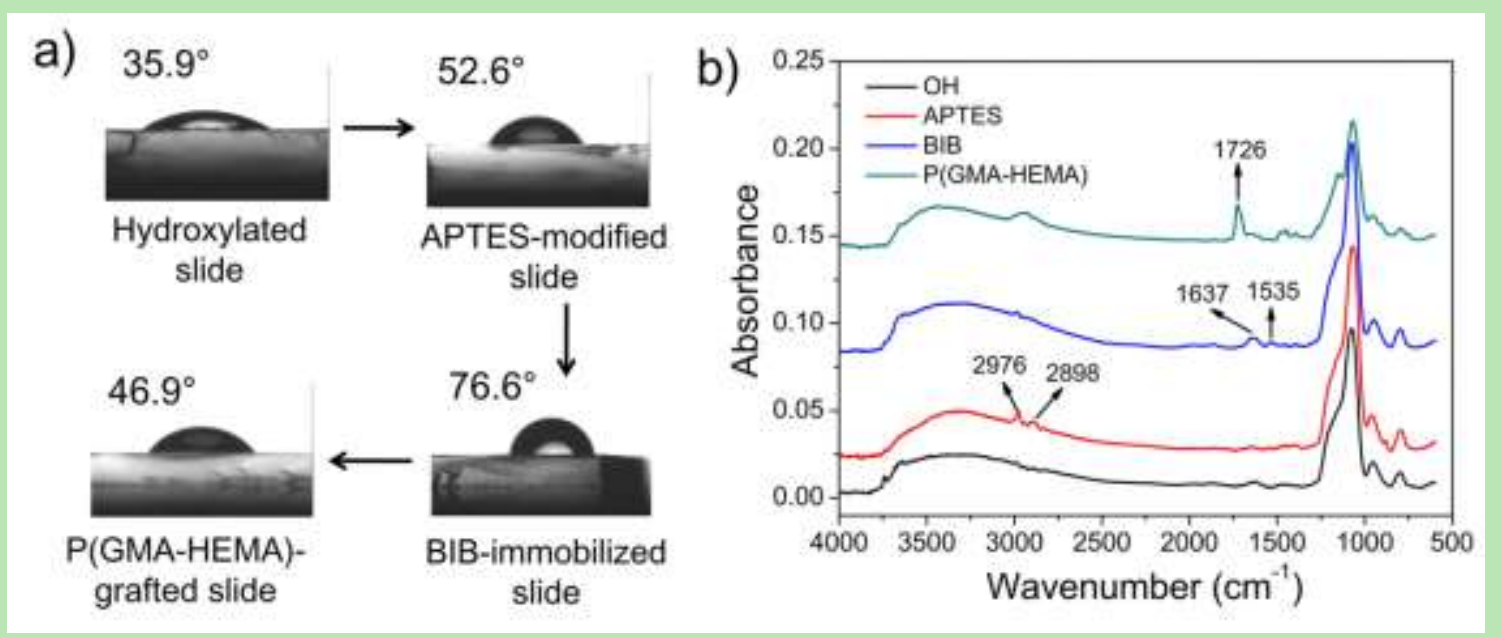

Figure S1 Water contact angles (WCAs) of the glass slides (a) and ATR-FTIR spectra of the silica particles (b) after stepwise surface modification. 

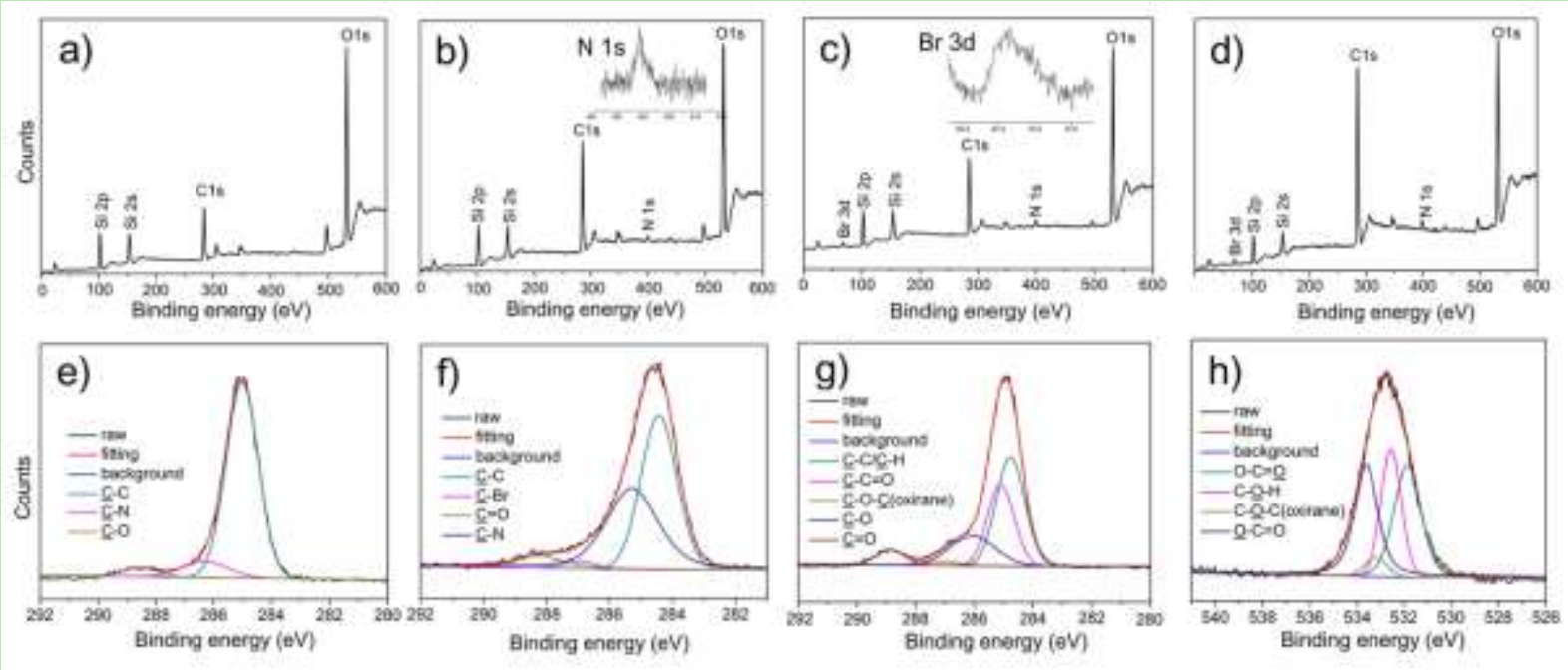

Figure S2 XPS wide scan of the glass slides (a-d): (a) hydroxylated slide, (b) APTES-modified slide, the inset is detailed $\mathrm{N}_{1 \mathrm{~s}}$, (c) BIB-immobilized slide, the inset is detailed $\mathrm{Br}_{3 \mathrm{~d}}$, and (d) P(GMA-HEMA)-grafted slide. High-resolution XPS $\mathrm{C}_{1 \mathrm{~s}}$ spectra and their peak fitting curves of glass slides (e-g): (e) APTES-modified slide, (f) BIB-immobilized slide, and (g) P(GMA-HEMA)-grafted slide. (h) High-resolution XPS $\mathrm{O}_{1 \mathrm{~s}}$ spectrum and the peak fitting curves of $\mathrm{P}(\mathrm{GMA}-\mathrm{HEMA})$-grafted glass slides. 


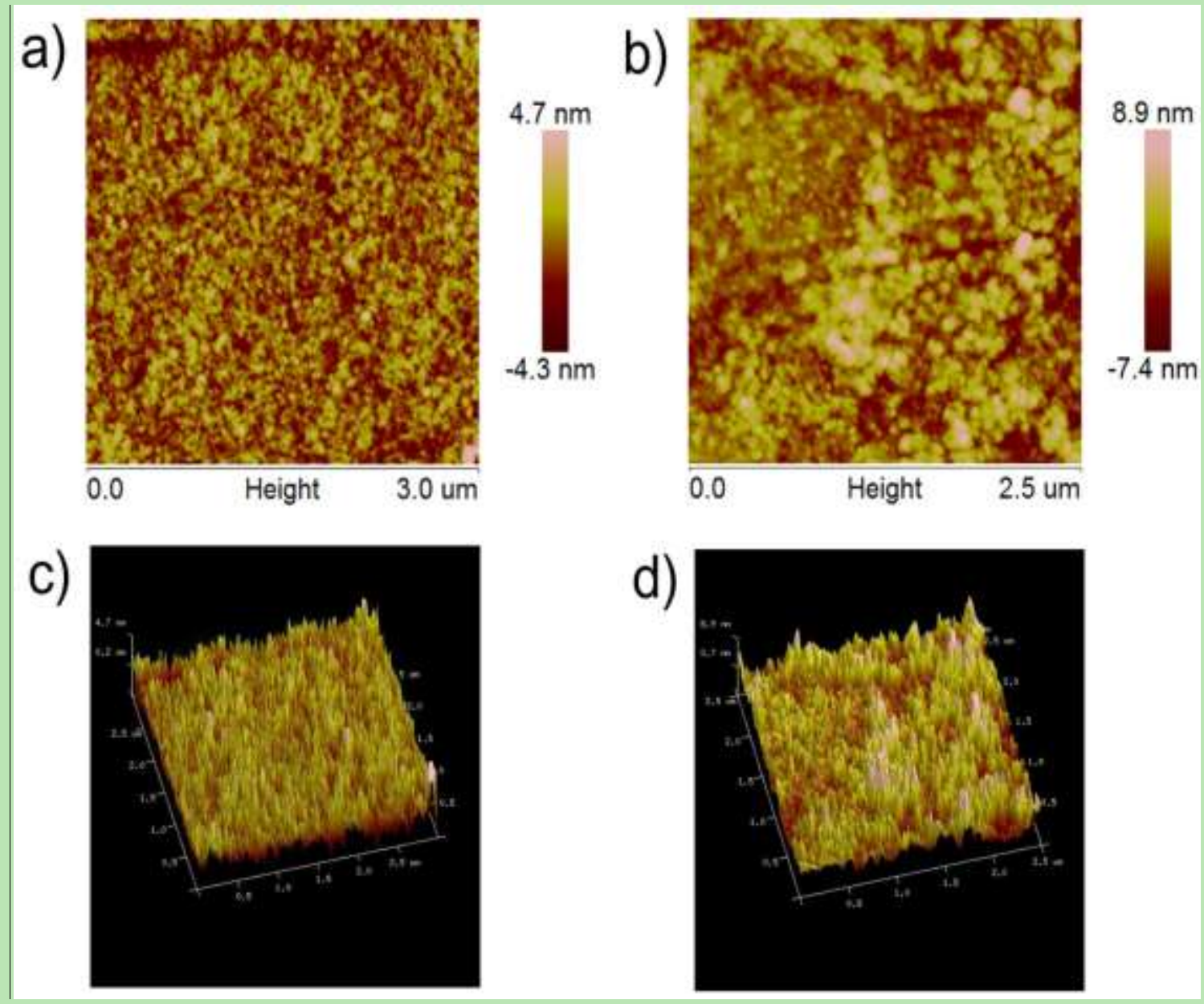

Figure S3 Tapping-mode AFM images and the corresponding three-dimensional images of the glass slide after washed by $\mathrm{KOH}$ and piranha solution $(\mathrm{a}, \mathrm{c})$ and grafted with $\mathrm{P}(\mathrm{GMA}-\mathrm{HEMA})$ brushes $(b, d)$. 


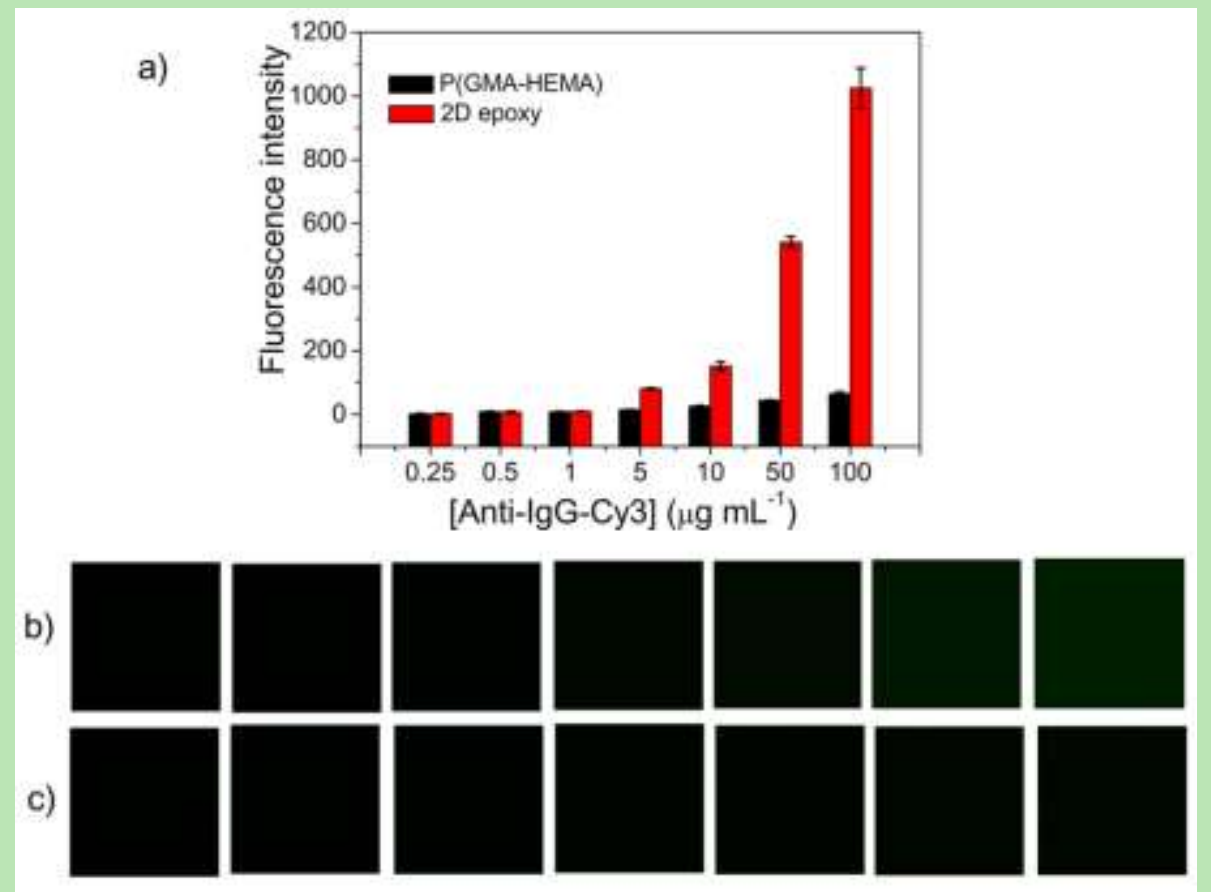

Figure S4 (a) The fluorescence intensities of nonspecific adsorbed rabbit antihuman IgG/Cy3 on the P(GMA-HEMA) brush-coated substrate and 2D epoxy slide. The fluorescence images of deactivated 2D epoxy slide (b) and P(GMA-HEMA) brush-coated substrate (c) after incubation with various concentrations of rabbit antihuman $\mathrm{IgG} / \mathrm{Cy} 3$.

Both of 2D epoxy slide and P(GMA-HEMA) brush substrate were incubated with PBS containing $1 \%(\mathrm{w} / \mathrm{v}) \mathrm{BSA}$ and $1 \%(\mathrm{v} / \mathrm{v})$ ethanolamine for $1 \mathrm{~h}$, then incubated with various concentrations of rabbit antihuman $\operatorname{IgG} / \mathrm{Cy} 3$ for $1 \mathrm{~h}$, respectively. The measured fluorescence intensities from 2D epoxy slides are increased with the increasing concentration of protein, and are much higher than those from the polymer brush-grafted slides, which remain almost constant. The result indicates that the P(GMA-HEMA) brush substrate has excellent resistance to nonspecific protein adsorption. 

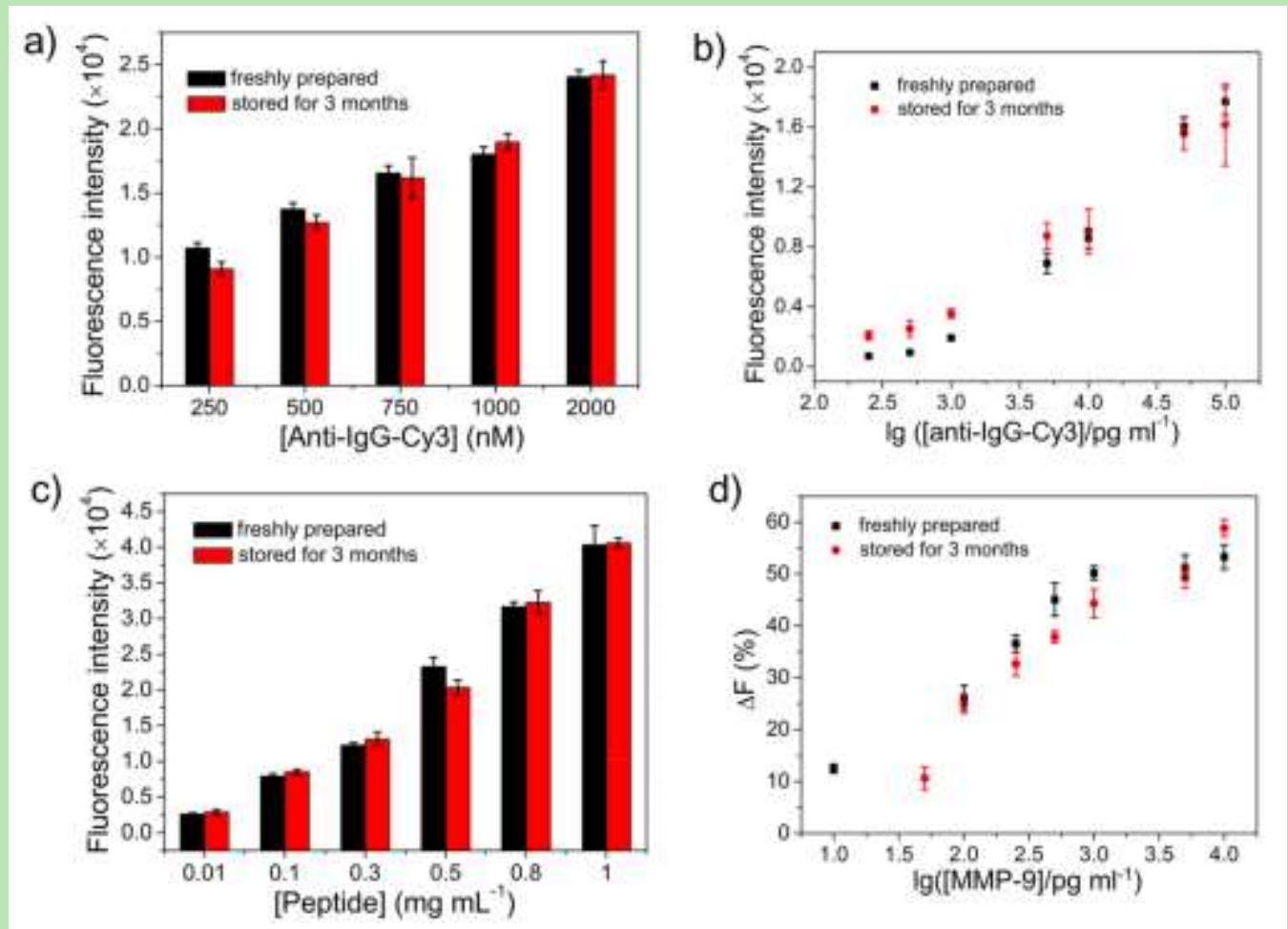

Figure S5 The stability of the as-prepared $\mathrm{P}($ GMA-HEMA) brush substrate. The P(GMA-HEMA) brush substrate has been stored at $4{ }^{\circ} \mathrm{C}$ for 3 months. Rabbit antihuman IgG/Cy3 molecules were directly immobilized (a) on the as-prepared P(GMA-HEMA) brush substrate or reacted with human IgG on the microarray spot (b). (c) Peptide molecules were directly immobilized and reacted with avidin-Cy3 on the as-prepared P(GMA-HEMA) brush substrate and (d) $\Delta \mathrm{F} \%$ of $\mathrm{S} 1$ after cleavage by MMP-9, respectively. The experimental conditions are as same as those of Figure 2 and Figure 3. 


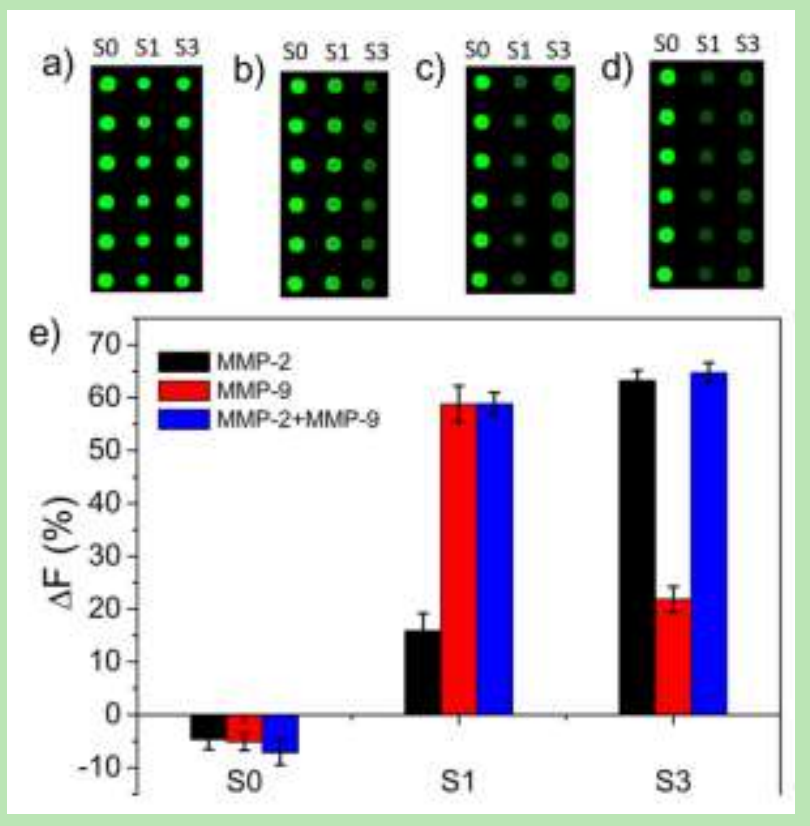

Figure S6 Fluorescence images of subarrays (a to d) and corresponding data analysis (e) of peptide substrates cleaved by MMPs. The peptide substrates were cleaved by (a) TCNB buffer, (b) MMP-2, (c) MMP-9, and (d) mixture of MMP-2 and MMP-9 for $2 \mathrm{~h}$, respectively. The concentrations of MMP-2 and MMP-9 are $10 \mathrm{ng} \mathrm{mL} \mathrm{m}^{-1}$. The concentrations of peptide substrates are $0.2 \mathrm{mg} \mathrm{mL}^{-1}$ for $\mathrm{S} 0, \mathrm{~S} 1$ and $\mathrm{S} 3$ in the spotting solutions. 

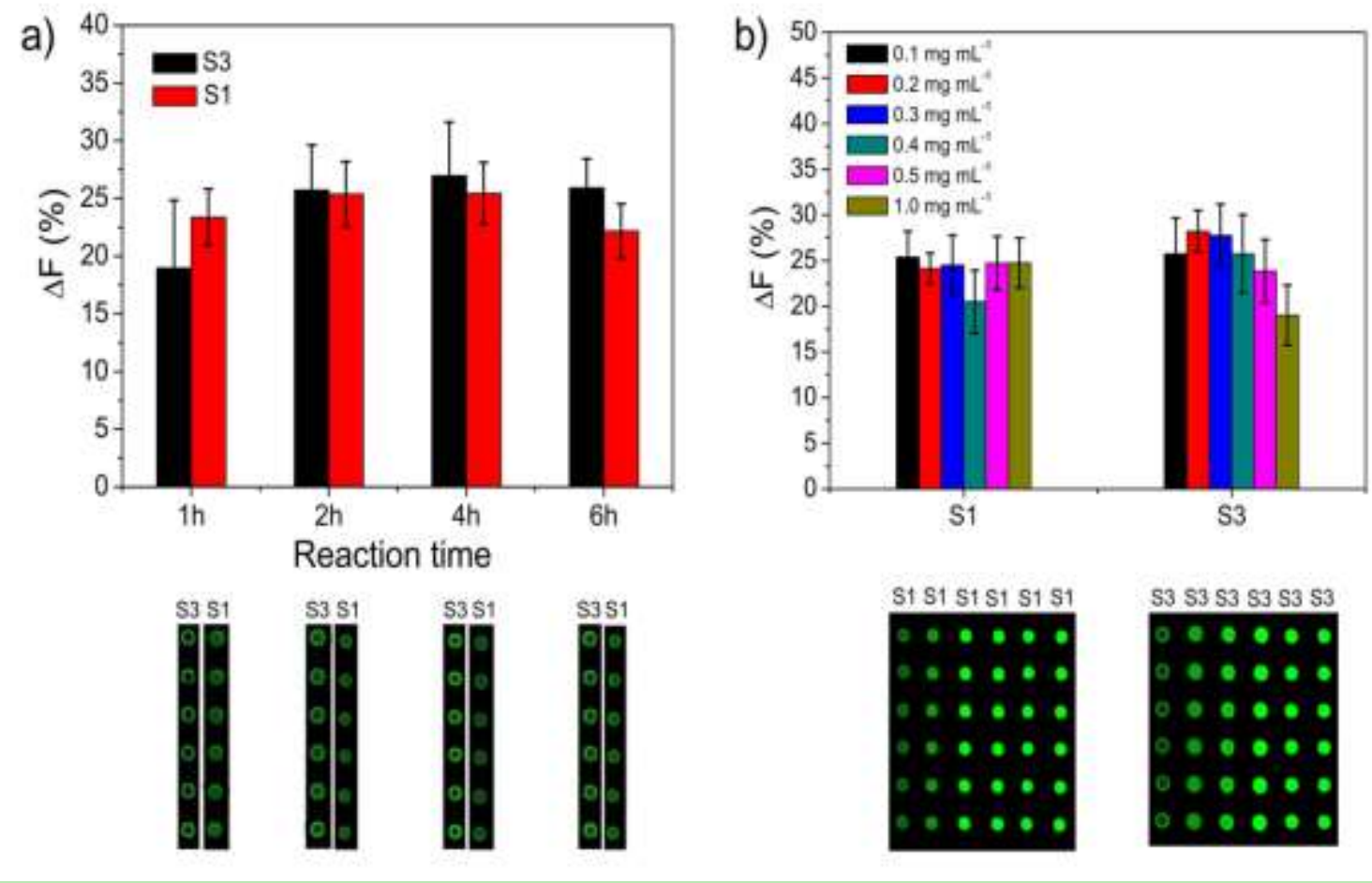

Figure S7 (a) Effects of the reaction time of enzyme cleavage and (b) the concentration of the substrate peptide in the spotting solution on the cleavage efficiencies of MMPs, and the corresponding fluorescence images. The concentrations of substrates S1 and S3 are $0.1 \mathrm{mg}$ $\mathrm{mL}^{-1}$ in the spotting solution in (a), and the reaction time is $2 \mathrm{~h}$ in (b). The concentrations of MMP-2 and MMP-9 are both $50 \mathrm{pg} \mathrm{mL}^{-1}$. 

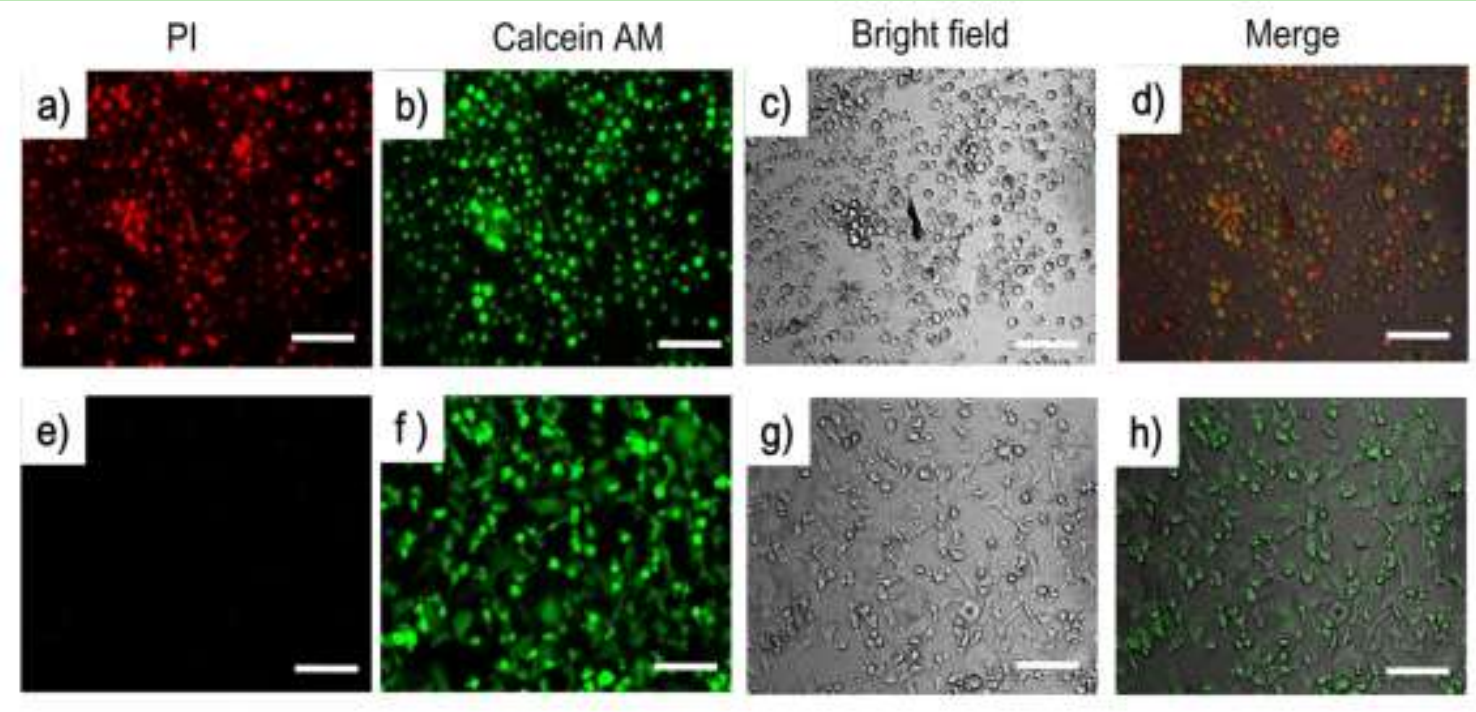

Figure S8 Fluorescence images of Calcein AM/PI co-stained cells cultured on the blank P(GMA-HEMA) brush substrate (a-d) and on the RGD-containing peptide spotted polymer brush-coated slide (e-h). The scale bars are $50 \mu \mathrm{m}$. 